\title{
Faktor-Faktor yang Mempengaruhi Tingkat Stress Wanita Usia Subur Penderita Diabetes Melitus di Puskesmas Putri Ayu Kota Jambi Tahun 2019
}

\author{
Dewi Nopiska Lilis ${ }^{1}$, Imelda ${ }^{2}$ \\ ${ }^{1-2}$ Politeknik kesehatan kemenkes Jambi Jurusan kebidanan \\ Email : dewinopiskalilis@gmail.com
}

Submitted : 16/01/2020

Accepted: 06/02/2020

Published: $14 / 03 / 2020$

\begin{abstract}
Diabetes in women of reproductive age needs to be observed and watched out for. Risks associated with gestational diabetes include pre-natal morbidity and death as well as an increase in chronic cesarean delivery and hypertension in the mother. This study aims to determine the effect of diabetes mellitus on the psychology of WUS in Jambi City in Putri Ayu Health Center in Jambi City in 2019.Data were analyzed using univariate analysis, bivariate with chi square and multivariate using logistic regression analysis. Fertile Age Women (WUS) with higher education have the opportunity not to stress with OR 0.2. WUS with impaired physical health have the opportunity not to stress with OR 4.2. WUS with problem solving skills have the opportunity to not stress with OR 4.2. WUS with high knowledge have a no stress opportunity with OR 0.2. The level of education, physical health, problem solving skills and the level of knowledge of WUS sufferers of diabetes mellitus significantly influence psychology (stress). This research is expected to be able to provide information on knowledge and be able to detect early on the factors that affect the stress level of sufferers of diabetes mellitus by using a scoring scale that can be utilized by health workers in the service and as a reference for diabetes mellitus patients.
\end{abstract}

Keywords: diabetes mellitus, psychology, stress, women of childbearing age

\begin{abstract}
Abstrak
Diabetes Mellitus pada perempuan usia reproduksi perlu dicermati dan diwaspadai. Risiko diabetes gestational adalah pra-natal morbiditas dan kematian serta peningkatan kelahiran sesar dan hipertensi yang kronis pada ibu. Penelitian ini bertujuan untuk mengetahui faktor-faktor yang mempengaruhi tingkat stress wanita usia subur penderita diabetes mellitus di Puskesmas Putri Ayu Kota Jambi Tahun 2019. Dengan rancangan Cross Sectional study, data dianalisis menggunakan analisis univariat, bivariat dengan chi square dan multivariat dengan menggunakan analisi Regresi Logistik. Wanita Usia Subur (WUS) dengan pendidikan tinggi mempunyai peluang untuk tidak stress dengan OR 0,2. WUS dengan kesehatan fisik terganggu mempunyai peluang tidak stress dengan OR 4,2. WUS dengan keterampilan memecahkan masalah mempunyai peluang untuk tidk stress dengan OR 4,2. WUS dengan pengetahuan tinggi mempunyai peluaang tidak stress dengan OR 0,2. Tingkat pendidikan, kesehatan fisik, keterampilan memecahkan masalah dan tingkat pengetahuan WUS penderita Diabetes Melitus berpengaruh secara signifikan terhadap psikologi (stress). Penelitian ini diharapakan dapat memberikan informasi pengetahuan dan dapat mendeteksi secara dini faktor-faktor yang mempengaruhi tingkat stress penderita Diabetes Melitus dengan pemakain skala scoring yang bisa dimanfaatkan oleh tenaga kesehatan di pelayanan dan sebagai acuan pasien Diabetes Melitus.
\end{abstract}

Kata kunci : diabetes melitus, stress, wanita usia subur

\section{PENDAHULUAN}

Diabetes mellitus (DM) merupakan salah satu ancaman utama bagi kesehatan umat manusia pada abad 21 (Nursalam,
2013). Diabetes melitus adalah salah satu penyakit tidak menular yang terjadi karena peningkatan kadar gula (glukosa) darah akibat kekurangan atau resistensi insulin di 
dalam tubuh. Diabetes adalah masalah kesehatan masyarakat yang penting, menjadi salah satu dari empat penyakit tidak menular prioritas yang menjadi target tindak lanjut oleh para pemimpin dunia. Jumlah kasus dan prevalensi diabetes terus meningkat selama beberapa dekade terakhir (WHO, 2016).

Pada Tahun 2015 prevalensi diabetes secara global mencapai $8,8 \%$ dan diperkirakan akan meningkat menjadi $10,4 \%$ di tahun 2040. Jumlah penderita diabetes sebanyak 415 juta jiwa di tahun 2015 yaitu pada usia (20-79 tahun) dan diperkirakan akan meningkat menjadi 642 juta jiwa di tahun 2040. Jumlah kematian yang disebabkan oleh diabetes sebanyak 5,0 juta jiwa di tahun 2015. Di tahun 2017 jumlah penderita diabetes melitus pada usia (20-79 tahun) di seluruh dunia sebanyak 425 juta jiwa dan diperkirakanakan meningkat menjadi 629 juta jiwa di tahun 2045. Indonesia menempati peringkat kedua kasus diabetes melitus terbanyak di wilayah barat Pasifik setelah China yang berada di peringkat pertama (IDF, 2017).

Menurut data estimasi WHO tahun 2016, Indonesia saat ini berada di peringkat keempat negara dengan jumlah penderita DM terbesar di dunia setelah China, India, dan Amerika. Total penderita diabetes melitus di Indonesia berdasarkan data WHO tahun 2000 sekitar 8,4 juta jiwa, dan diperkirakan jumlahnya melebihi 21,3 juta jiwa pada tahun 2030 mendatang (WHO, 2016).

Prevalensi penderita diabetes melitus di Indonesia dari hasil Riskesdas menunjukkan tren peningkatan. Prevalensi diabetes mellitus pada tahun 2007 sebesar $1,5 \%$ dan meningkat menjadi $2,1 \%$ padatahun 2013. Jika dibandingkan dengan tahun 2013, prevalensi diabetes melitus berdasarkan diagnosis dokter pada penduduk umur $\geq 15$ tahun hasil Riskesdas 2018 meningkat menjadi 2\%. Prevalensi diabetes melitusdi Provinsi Jambi dari hasil Riskesdas provinsi Jambi sebesar 0,5\% pada tahun 2007 meningkat menjadi 1,1\% pada tahun 2013 dan 1,5\% pada tahun 2018 (Riskesdas, 2018).

Diabetes melitus terbagi menjadi 2, tipe pertama yaitu diabetes melitus tipe I (tergantung pada insulin) disebabkan insulin yang dihasilkan oleh pankreas sangat sedikit atau bahkan sama sekali tidak ada insulin yang dihasilkan, kebanyakan diabetes tipe 1 adalah anak-anak dan remaja yang pada umumnya tidak gemuk. Kedua diabetes melitus tipe II (tidak tergantung pada insulin) jika insulin hasil produksi pankreas tidak cukup atau sel lemak dan otot tubuh menjadi kebal terhadap insulin, sehingga terjadilah gangguan pengiriman gula ke sel tubuh. Diabetes tipe II ini merupakan tipe diabetes yang paling umum dijumpai, sehingga sering disebut diabetes yang dimulai pada masa dewasa, dikenal sebagai NIDDM (Non Insulin Dependent Diebetes Mellitus) diabetes tipe II terjadi akibat obesitas, aktivitas fisik, diet, pola konsumsi yang tidak sehat, dan lain-lain (Bustan, 2007).

Kejadian diabetes miletus tipe 2 pada wanita lebih tinggi daripada lakilaki.Wanita lebih berisiko mengidap diabetes karena secara fisik wanita memiliki peluang peningkatan indeks masa tubuh yang lebih besar. Sindroma siklus bulanan (premenstrual syndrome), pascamenopouse yang membuat distribusi lemak tubuh menjadi mudah terakumulasi akibat proses hormonal tersebut sehingga wanita berisiko menderita diabetes melitus tipe II (Wahyuni, 2007).

Dalam laporan Riskesdas tahun 2007 tidak disebutkan prevalensi diabetes pada perempuan usia reproduksi (15-49 tahun) atau usia subur, dengan kata lain belum ada laporan nasional melaporkan kejadian diabetes melitus pada rentang usia reproduksi. Pada Riskesdas Diabetes melitus merupakan masalah kesehatan yang penting bagi perempuan usia reproduksi. Diabetes melitus yang tidak terkontrol atau tidak terdiagnosis pada usia tersebut dapat 
mengakibatkan komplikasi pada saat kehamilan yang mengancam jiwa ibu atau persalinan yang sulit, dan komplikasi yang mengancam kehidupan dan kesehatan anak yang baru lahir. Bayi yang dilahirkan dari ibu yang mempunyai riwayat gestasional diabetes melitus (GDM) akan berisiko mengalami diabetes melitus tipe 2 .

Persentase DM pada perempuan usia reproduksi perlu dicermati dan diwaspadai. Risiko yang terkait diabetes gestational adalah pra-natal morbiditas dan kematian serta peningkatan kelahiran sesar dan hipertensi yang kronis pada ibu. Wanita dengan diabetes gestational lebih cenderung melahirkan bayi besar yang merupakan alasan mengapa lebih banyak perempuan dengan diabetes gestasional melakukan sesar pada saat persalinan. Wanita dengan diabetes sebelum kehamilan lebih cenderung memiliki bayi dengan cacat bawaan jika kontrol glikemik mereka dibawah optimal selama trimester pertama kehamilan. Dengan demikian sangat penting untuk semua wanita dengan diabetes untuk diberi konseling tentang risiko hiperglikemia dan kehamilan sebelum konsepsi dan untuk wanita dengan diabetes untuk merencanakan kehamilan mereka sehingga untuk mengurangi risiko cacat bawaan pada keturunan mereka.

Segala macam komplikasi yang dialami oleh penderita DM tipe 2 tersebut menyebabkan perubahan besar pada tubuh mereka. Perubahan besar tersebut menyebabkan stress. Menurut Selye (dalam Perry \& Potter), bahwa stress adalah segala situasi dimana tuntutan nonspesifik mengharuskan seorang individu untuk berespon atau melakukan tindakan (Potter, 2005). Stress dapat menyebabkan perasaan negatif atau yang berlawanan dengan apa yang diinginkan atau mengancam kesejahteraan dan emosional. Stress dapat mengganggu cara seseorang menyerap realitas,menyelesaikan masalah, berpikir secara umum, dan hubungan seseorang dan cara memiliki. Situasi stress berat yang dialami oleh penderita DM tipe 2 adalah situasi kronis yang berlangsung beberapa minggu sampai beberapa tahun yang menyebabkan resiko kesehatan semakin tinggi (Sofiana, 2012).

Sesuai dengan penelitian Saraswati tentang hubungan antara konsep diri dan tingkat perubahan psikologis antara lain perubahan konsep diri dan depresi (Saraswati, 2010). Stress psikologis dapat timbul pada saat seseorang menerima diagnosa DM. Mereka beranggapan bahwa DM akan menimbulkan banyak permasalahan seperti pengendalian diet serta terapi yang lama dan kompleks. Pasien dengan diabetes mellitus (DM) sejak saat didiagnosis membutuhkan dukungan psikologis sepanjang rentang hidup mereka. Menyusun psikologis pasien DM memainkan peran sentral dalam perilaku manajemen diri. Tanpa kepatuhan pasien terhadap terapi yang efektif, kontrol suboptimal yang gigih, akan meningkatkan komplikasi terkait diabetes, yang menyebabkan penurunan kualitas hidup, sehingga meningkatkan utilisasi dan beban kesehatan pada sistem layanan kesehatan (Chew, 2015).

\section{METODE PENELITIAN}

Penelitian ini menggunakan metode kuantitatif, melalui proses pengumpulan data dengan cara memberikan sejumlah pertanyaan (Creswell, 1994). Dengan desain deskriptif dan pendekatan Cross Sectional Study, dimana hubungan variabel bebas dengan variabel terikat dilakukan sesaat dan secara bersamaan. Variabel terikat dalam penelitian ini adalah psikologi wus penderita DM, sedangkan variabel bebasnya adalah tingkat pendidikan, kesehatan fisik wus penderita diabetes, keterampilan memecahkan masalah, dan tingkat pengetahuan

Penelitian ini dilakukan di Puskesmas Putri Ayu Kota Jambi, waktu penelitian 
pada bulan April- November 2019. Populasi dalam penelitian ini adalah wanita usia subur di Puskesmas Putri Ayu Kota Jambi Tahun 2019. Peneliti menggunakan tehnik purposive sampling untuk menentukan jumlah wus sebagai sampel penelitian. Purposive sampling adalah cara memilih responden berdasarkan pada pertimbangan secara subyektif, dimana responden dapat memberikan informasi yang memadai untuk menjawab pertanyaan. Dalam penelitian ini, peneliti memilih sebanyak 68 orang WUS.

Kriteria Inklusi: a) Wanita usia subur berusia 15 - 49 tahun; b)Sudah menikah, c) Bersedia untuk diperiksa gula darahnya, d) Bersedia menjadi responden dibuktikan dengan menandatangani informed consent

Kriteria Ekslusi: a) Sedang Hamil; b) Kadar Glukosa darah sewaktu $<200$ mg/dl; c) Beralamat diluar wilayah kerja Puskesmas

Proses pengumpulan data dalam penelitian ini adalah dengan menggunakan angket (kuesioner) dan lembar persetujuan menjadi responden. Lembar persetujuan dan kuesioner akan dibagikan kepada WUS terpilih, kemudian peneliti mpersilahkan responden untuk mengisi kuesioner. Peneliti memberikan kesempatan bertanya kepada responden selama proses pengisian kuesioner apabila ada pertanyaan yang tidak dimengerti oleh responden. Setelah kuesioner selesai diisi oleh responden, selanjutnya dikembalikan kepada peneliti. Kemudian peneliti memastikan responden telah mengisi semua pertanyaan di dalam kuesioner. Setelah itu seluruh data dikumpulkan untuk selanjutnya dianalisa.

Proses analisa data untuk mendapatkan hasil dilakukan dengan analisis univariat (analisis deskriptif), bivariat, dan multivariat. Analisis bivariat menggunakan uji Chi Square, dan analisis multivariat menggunakan regresi logistik.

\section{HASIL DAN PEMBAHASAN}

1. Analisis univariat

Analisis univariat merupakan analisis yang menampilkan dari karakteristik responden yang diteliti. Pada Tabel 1 di bawah terlihat bahwa rerata tinggi badan Wanita Usia Subur (WUS) penderita Diabetes Melitus (DM) adalah 156,2 cm dengan tinggi badan tertinggi $168 \mathrm{~cm}$ dan terendah $145 \mathrm{~cm}$. Rerata berat badan Wus penderita DM sebesar 58,6 kg dengan berat terendah $35 \mathrm{~kg}$ dan tertinggi $90 \mathrm{~kg}$. Tekanan sistole reratanya sebesar 117,2 dengan sistole terendah 100 dan tertinggi 196. Rerata tekanan darah diastole 75,9 dengan rentang antara 60-90. Gula darah terukur yang diperoleh dengan rata-rata 223,6 dengan gula darah terendah 190 dan tertinggi 443.

Hasil dari diabetes militus distres yang terbagai menjadi 4 komponen yaitu emosi, susah berkaitan dengan hubungan dokter, gangguan berkaitan dengan rejimen dan sistres interpersonal adalah sebagai berikut: 1) rerata nilai emosi yaitu 2,1 dengan nilai rerata terendah 1 dan tertinggi $5,2 ; 2)$ susah berkaitan dengan dokter diperoleh rata-rata sebesar 2,4 dengan nilai rerata terendah 1 dan tertinggi $5 ; 3$ ) gangguan berkaitan dengan regimen nilai rerata yang diperoleh 2,3 dengan rentang rerata terendah 1 dan tertinggi 5,$6 ; 4$ ) distres interpersonal nilai rerata yang diperoleh 2,4 dengan rerata terendah 1 dan tertinggi 6. Hasil dari 4 komponen ini selanjutnya dijumlahkan sebagai psikologi distres. Rerata psikologi distres yang diperoleh adalah 2,8 dengan rerata terendah 1 dan tertinggi 4,6. Dari masing-masing komponen ini selanjutnya dikategorikan berdasarkan 6 penilaian yang ada.

Pekerjaan WUS secara umum terbagi menjadi tiga yaitu sebagai PNS, swasta dan ibu rumah tangga. Dari 68 responden yang bekerja sebagai PNS ada 7 orang (10,3\%), swasta 23 orang $(33,8 \%)$ dan paling banyak adalah ibu rumah tangga yaitu 38 orang $(55,9 \%)$. Pendidikan formal yang dienyam 
oleh Wus penderita DM dari SD sampai perguruan tinggi dengan jumlah untuk SD ada $3(4,4 \%)$, SLTP 17 orang (25\%), SLTA 30 orang $(44,1 \%)$, D3 14 orang $(20,6 \%)$ dan S1 ada 4 orang $(5,9 \%)$. Pendidikan ini selanjutnya untuk kepentingan analisis dibagi menjadi 2 yaitu tingkat pendidikan rendah dari SLTP ke bawah, dan tinggi dari SLTA ke atas.

Kriteria emosi dari komponen emosi dari diabetus melitus distres terbagi menjadi 5 kriteria yaitu yang menganggap tidak mengalami masalah emosi ada $16(23,5 \%)$, mengalami sedikit masalah dengan emosi ada $18(26,5 \%)$, merasa bahwa emosi merupakan masalah yang sedang ada $21(30,9 \%)$, merasa bahwa emosi merupakan masalah yang agak serius ada $11(16,2 \%)$ dan yang merasa bahwa emosi merupakan masalah yang serius ada 2 $(2,9 \%)$. Dari kriteria emosi ini sebagian besar merasa bukan merupakan masalah yang serius.

Kriteria susah berkaitan dengan dokter dari 6 kriteria penilaian diperoleh 5 kriteria yaitu merasa tidak mengalami masalah sebesar 39 orang $(57,4 \%)$, menganggap merupakan sedikit masalah ada 7 orang $(10,3 \%)$, menganggap merupakan masalah sedang berjumlah 11 orang $(16,2 \%)$, sisanya yaitu 9 orang $(13,2 \%)$ menganggap merupakan masalah yang agak serius dan 2 orang $(2,9 \%)$ menganggap merupakan masalah serius. Dari persentase yang diperoleh ini sebagian besar responden menganggap hubungan dengan dokter bukan merupakan suatu masalah yang serius.

Komponen kriteria gangguan berkaitan dengan rejimen dari 6 penilaian diperoleh 5 kriteria yaitu bukan merupakan masalah ditemukan ada 38 orang $(55,9 \%)$, menganggap merupakan sedikit masalah ada 7 orang $(10,3 \%)$, merupakan masalah yang sedang 7 orang $(10,3 \%)$, menganggap merupakan masalah yanga agak serius ada 14 orang $(20,6 \%)$ dan 2 orang $(2,9)$ menganggap merupakan masalah yang serius.

Kriteria distres interpersonal diperoleh 6 kriteria yaitu merasa tidak mengalami masalah sebesar 38 orang $(55,9 \%)$, menganggap merupakan sedikit masalah ada 5 orang $(7,4 \%)$, menganggap merupakan masalah sedang berjumlah 8 orang $(11,8 \%)$, sisanya yaitu 12 orang $(17,7 \%)$ menganggap merupakan masalah yang agak serius 4 orang $(5,8 \%)$ menganggap merupakan masalah serius dan 1 orang $(1,4 \%)$ menganggap masalah serius. Dari persentase yang diperoleh ini sebagian besar responden menganggap hubungan dengan dokter bukan merupakan suatu masalah yang serius.

Hasil dari pengukuran psikology WUS penderita DM dari 6 klasifikasi yang ada hanya diperoleh 5 klasifikasi yaitu tidak mengalami masalah, sedikit mengalami masalah, masalah sedang, masalah agak serius, mengalami masalah serius. Dari 5 klasifikasi yang diperoleh untuk Wus penderita DM yang merasa tidak mengalami masalah ada $4(5,8 \%)$, sedikit mengalami masalah 34 (50,0\%), menganggap masalah sedang $5(7,4 \%)$, merasa bahwa merupakan masalah agak serius $14(20,6 \%)$ dan terakhir yang menganggap masalah serius ada 11 $(16,2 \%)$. Hasil klasifikasi ini sesuai dengan petunjuk penggunaan kuesioner DDS dibagi menjadi 2 yaitu WUS yang berada pada klasifikasi sedang ke bawah di klasifikasikan sebagai WUS yang tidak mengalami stress, sedangkan yang berada pada klasifikasi agak serius ke atas diklasifikasikan sebagai WUS yang mengalami stress. Hasil analisis karakteristik responden secara lengkap disajikan pada Tabel 1 . 
Jurnal Akademika Baiturrahim Jambi, Vol. 9, No.1 Maret 2020

Doi: $10.36565 /$ jab.v9i1.196

p-ISSN :2302-8416

e-ISSN: 2654-2552

Tabel 1. Karakteristik Responden Wanita Usia Subur penderita Diabetes Melitus

\begin{tabular}{|c|c|c|}
\hline Variabel & $\begin{array}{c}\text { mean } \pm s d \\
\mathrm{n}(68)\end{array}$ & $\begin{array}{c}\text { Min-max } \\
\%\end{array}$ \\
\hline Tinggi badan & $156,2 \pm 5,3$ & $145-168$ \\
\hline Berat badan & $58,6 \pm 11,7$ & $35-90$ \\
\hline Sistole & $117,2 \pm 13,4$ & $100-196$ \\
\hline Diastole & $75,9 \pm 6,9$ & $60-90$ \\
\hline Gula darah (mmg/l) & $223,6 \pm 38,0$ & $190-443$ \\
\hline Emosi & $2,8 \pm 1,1$ & $1-5,2$ \\
\hline Susah berkaitan dengan dokter & $2,1 \pm 1,3$ & $1-5$ \\
\hline Gangguan berkaitan dengan regimen & $2,1 \pm 1,3$ & $1-5,6$ \\
\hline Distres interpersonal & $\begin{array}{l}2,4 \pm 1,5 \\
23 \pm 16\end{array}$ & $1-6$ \\
\hline Psikology distres & $2,3 \pm 1,6$ & $1-4,6$ \\
\hline Pekerjaan wus penderita DM & $2,4 \pm 1,2$ & \\
\hline PNS & & 10,3 \\
\hline Swasta & 7 & 33,8 \\
\hline Tidak bekerja/IRT & 23 & 55,9 \\
\hline Pendidikan yang ditempuh & 38 & \\
\hline $\mathrm{SD}$ & & 4,4 \\
\hline SLTP & 3 & 25,0 \\
\hline SLTA & 17 & 44,1 \\
\hline D3 & 30 & 20,6 \\
\hline S1 & 14 & 5,9 \\
\hline Kriteria emosi & 4 & \\
\hline Tidak mengalami masalah & & 23,5 \\
\hline Sedikit mengalami masalah & 16 & 26,5 \\
\hline Masalah sedang & 18 & 30,9 \\
\hline Masalah agak serius & 21 & 16,2 \\
\hline Mengalami masalah serius & 11 & 2,9 \\
\hline Kriteria susah berkaitan dengan dr & 2 & \\
\hline Tidak mengalami masalah & & 57,4 \\
\hline Sedikit mengalami masalah & 39 & 10,3 \\
\hline Masalah sedang & 7 & 16,2 \\
\hline Masalah agak serius & 11 & 13,2 \\
\hline Mengalami masalah serius & 9 & 2,9 \\
\hline Kriteria gangguan berkaitan dengan rejimen & 2 & \\
\hline Tidak mengalami masalah & & 55,9 \\
\hline Sedikit mengalami masalah & 38 & 10,3 \\
\hline Masalah sedang & 7 & 10,3 \\
\hline Masalah agak serius & 7 & 20,6 \\
\hline Mengalami masalah serius & 14 & 2,9 \\
\hline Distres interpersonal & 2 & \\
\hline Tidak mengalami masalah & & 55,9 \\
\hline Sedikit mengalami masalah & 38 & 7,4 \\
\hline Masalah sedang & 5 & 11,8 \\
\hline Masalah agak serius & 8 & 17,7 \\
\hline Mengalami masalah serius & 12 & 5,8 \\
\hline Mengalami masalah sangat serius & 4 & 1,4 \\
\hline Psikologi Wus penderita DM & 1 & \\
\hline Tidak mengalami masalah & & 5,8 \\
\hline Sedikit mengalami masalah & 4 & 50,0 \\
\hline Masalah sedang & 34 & 7,4 \\
\hline Masalah agak serius & 5 & 20,6 \\
\hline Mengalami masalah serius & $\begin{array}{l}14 \\
11\end{array}$ & 16,2 \\
\hline
\end{tabular}


Pada analisis Tabel 2 dapat dijelaskan bahwa Wanita Usia Subur (WUS) penderita Diabetes Melitus (DM) yang mengalami gangguan psikologi relatif besar mencapai $36,7 \%$ hal ini dapat dimungkinkan bahwa seseorang yang teridentifikasi DM akan merasa terganggu perasaannya terutama seorang ibu yang masih subur. Tingkat pendidikan responden sebagian besar berpendidikan tinggi yaitu SLTA ke atas. Ini menunjukkan bahwa tingkat pendidikan responden hampir merata jenjangnya dan tingkat pemahamannya terhadap bahaya DM bagi Wus lebih tinggi. Dari responden yang sudah teridentifikasi menderita DM, kesehatan fisik yang tidak terganggu lebih besar daripada yang terganggu, ini bisa dipahami bahwa sebagian besar responden mempunyai pendidikan yang tinggi. Dengan pendidikan yang tinggi maka tingkat pengetahuannya lebih luas sehingga berusaha untuk mencegah agar kesehatannya tidak terganggu. Hal ini juga diperkuat dari karakteristik keterampilan responden. Pada variabel keterampilan responden dalam memecahkan masalah terdapat lebih dari $64 \%$ responden terampil dalam memecahkan masalah yang berkaitan dengan DM. Terampil di sini berarti responden terampil dalam mencegah agar DM tidak menjadikan kesehatannya responden lebih erganggu sehingga terjadi komplikasi. Pada variabel tingkat pengetahuan Wus penderita DM juga terlihat bahwa lebih dari 50\% responden mempunyai pengetahuan yang tinggi tentang DM. Dari karakteristik responden di atas dapat disimpulkan bahwa responden mempunyai kepekaan yang positif terhadap penyakit DM sehingga diharapkan responden mampu untuk menyelesaikan masalah. Hasil analisis karakteristik responden berdasarkan variabel secara lengkap disajikan pada Tabel 2 di bawah ini.

Tabel 1 Karakteristik Wanita Usia Subur penderita Diabetes Mellitus

\begin{tabular}{lcc}
\hline Variabel & $\mathrm{n}(68)$ & $\%$ \\
\hline Psikologi WUS penderita DM & & \\
$\quad$ Tidak stres & 43 & 63,4 \\
$\quad$ stres & 25 & 36,7 \\
Tingkat pendidikan WUS penderita DM & 48 & 70,6 \\
$\quad$ Tinggi & 20 & 29,4 \\
$\quad$ Rendah & & \\
Kesehatan fisik WUS penderita DM & 59 & 86,8 \\
$\quad$ Tidak terganggu & 9 & 13,2 \\
$\quad$ Terganggu & & \\
Keterampilan memecahkan masalah & 44 & 64,7 \\
$\quad$ Terampil & 24 & 35,3 \\
$\quad$ Tidak terampil & & 52,9 \\
Tingkat pengetahuan WUS penderita DM & 36 & 47,1 \\
$\quad$ Tinggi & 32 & \\
Rendah & & \\
\hline
\end{tabular}

2. Analisis bivariabel

Analisis bivariat merupakan analisis untuk menguji antara variabel bebas terhadap variabel terikat. Pada analisis ini digunakan uji Chi Square untuk menguji seberapa besar variabel bebas berpengaruh terhadap variabel terikat. Nilai alpha $(p)$ yang digunakan untuk menentukan batasan kemaknaan pengaruh variabel bebas terhadap variabel terikat sebesar 0,05 yang 
berarti bahwa bila dalam uji Chi Square nilai $\mathrm{p}$ yang diperoleh lebih kecil dari 0,05 maka variabel bebas berpengaruh terhadap variabel terikat, tetapi sebaliknya bila nilai $\mathrm{p}$ yang diperoleh lebih besar sama dengan 0,05 maka variabel bebas tidak berpengaruh terhadap variabel terikat. Hasil analisis Chi
Square antara variabel bebas yaitu tingkat pendidikan, kesehatan fisik, keterampilan memecahkan masalah, dan tingkat pengetahuan WUS penderita DM terhadap variabel terikat yaitu psikologi WUS pada penelitian ini secara lengkap disajikan pada Tabel 3.

Tabel 3 Pengaruh tingkat pendidikan, kesehatan fisik, keterampilan memecahkan masalah dan tingkat pengetahuan WUS penderita DM di Puskesmas Putri Ayu Kota Jambi terhadap Psikologi WUS penderita DM

\begin{tabular}{|c|c|c|c|c|c|c|}
\hline \multirow{3}{*}{ Variabel } & \multicolumn{4}{|c|}{$\begin{array}{c}\text { Psikologi Wus penderita } \\
\text { DM }\end{array}$} & \multirow{3}{*}{ OR } & \multirow{3}{*}{$\mathrm{P}$} \\
\hline & \multicolumn{2}{|c|}{ Tidak stress } & \multicolumn{2}{|c|}{ Stress } & & \\
\hline & $\mathrm{N}$ & $\%$ & $\mathrm{n}$ & $\%$ & & \\
\hline \multicolumn{7}{|c|}{ Tingkat pendidikan Wus penderita DM } \\
\hline Tinggi & 26 & 60,5 & 22 & 88,0 & \multirow[t]{2}{*}{0,2} & \multirow[t]{2}{*}{0,02} \\
\hline Rendah & 17 & 39,5 & 3 & 12,0 & & \\
\hline \multicolumn{7}{|c|}{ Kesehatan fisik Wus penderita DM } \\
\hline Tidak terganggu & 40 & 93,0 & 19 & 76,0 & \multirow[t]{2}{*}{4,2} & \multirow[t]{2}{*}{0,04} \\
\hline Terganggu & 3 & 7,0 & 6 & 24,0 & & \\
\hline \multicolumn{7}{|c|}{ Keterampilan memecahkan masalah } \\
\hline Terampil & 33 & 76,7 & 11 & 44,0 & \multirow[t]{2}{*}{4,2} & \multirow[t]{2}{*}{0,006} \\
\hline Tidak terampil & 10 & 23,3 & 14 & 56,0 & & \\
\hline \multicolumn{7}{|c|}{ Tingkat pengetahuan Wus penderita DM } \\
\hline Tinggi & 17 & 39,5 & 19 & 76,0 & \multirow[t]{2}{*}{0,2} & \multirow[t]{2}{*}{0,003} \\
\hline Rendah & 26 & 60,5 & 6 & 24,0 & & \\
\hline
\end{tabular}

Hasil analisis pada Tabel 3 secara umum menunjukkan bahwa secara umum variabel bebas yaitu tingkat pendidikan, kesehatan fisik, keterampilan memecahkan masalah dan tingkat pengetahuan Wus penderita DM berpengaruh secara signifikan terhadap psikologi Wus penderita DM dengan nilai $\mathrm{p}$ di bawah 0,05 .

Pada variabel pendidikan Wus penderita DM terlihat bahwa dari 68 responden terdapat 48 responden yang berpendidikan tinggi dan nilai OR (ods Rasio) yang diperoleh sebesar 0,2 dengan nilai $\mathrm{p}$ sebesar 0,02 . Hasil ini menunjukkan bahwa Wus dengan pendidikan tinggi mempunyai peluang untuk tidak stres dalam menghadapi DM sebesar 20\% dibandingkan Wus yang berpendidikan rendah. Hal ini dapat dimungkinkah karena Wus yang berpendidikan tinggi mempunyai kemampuan wawasan yang lebih baik dibandingkan Wus yang berpendidikan rendah. Nilai $\mathrm{p}$ sebesar 0,02 menunjukkan bahwa variabel tingkat pendidikan berpengaruh secara signifikan terhadap psikologi Wus penderita DM artinya ada perbedaan yang signifikan antara ibu yang berpendidikan tinggi terhadap psikologi wus dalam mengahadapi penyakit DM.

Untuk variabel kesehatan fisik wus penderita DM terlihat bahwa dari 68 Wus yang kesehatan fisiknya tidak terganggu karena DM ada 59 orang. Dari 59 orang ini yang tidak mengalami stress sebanyak 40 orang dan yang mengalami stres ada 19 orang. Sedangkan jumlah responden yang kesehatan fisiknya terganggu ada 9 orang dengan 3 orang tidak mengalami stress sedangkan yang 6 mengalami stress. Dari hasil uji Chi Square diperoleh nilai $p$ 
sebesar 0,04 yang berarti bahwa terdapat hubungan yang signifikan antara Wus penderita DM yang kesehatan fisiknya tidak terganggu terhadap psikologi Wus penderita DM. Nilai OR yang diperoleh dari uji Chi Square sebesar 4,2 yang berarti bahwa Wus penderita DM dengan kesehatan fisik yang tidak terganggu akibat DM mempunyai peluang 400,2\% untuk tidak stres dibandingkan Wus penderita DM yang kesehatan fisiknya terganggu. Dari hasil ini dapat disimpulkan bahwa Wus yang kesehatan fisiknya tidak terganggu peluang untuk tidak mengalami gangguan psikologi lebih besar dibandingkan Wus yang kesehatan fisiknya terganggu akibat DM.

Pada variabel keterampilan memecahkan masalah terdapat 44 Wus penderita DM yang terampil dalam memecahkan masalah. Dari 44 Wus penderita DM terampil dalam memecahkan masalah terdapat 33 orang yang tidak stres sedangkan 11 orang mengalami stres. Hasil analisis uji Chi Square diperoleh nilai $p$ sebesar 0,006 yang menunjukkan bahwa ada pengaruh yang siginifikan Wus penderita DM dengan keterampilan memecahkan masalah untuk tidak mengalami gangguan psikologi. Nilai OR yang diperoleh sebesar 4,2 ini berarti bahwa Wus penderita DM dengan kemampuan keterampilan memecahkan masalah mempunyai peluangan $400,2 \%$ untuk tidak mengalami stress dibandingkan Wus yang tidak mempunyai keterampilan memecahkan masalah. Hasil ini menunjukkan bahwa Wus yang terampil dalam memecahkan permasalahan yang berkaitan dengan penyakit DM berpeluang lebih besar untuk tidak stress dibandingkan ibu yang tidak mempunyai keterampilan.

pada variabel tingkat pengetahuan Wus dari hasil analisis dapat dilihat bahwa terdapat 36 Wus penderita DM dengan tingkat pengetahuan tinggi dengan 17 orang tidak mengalami stress dan 19 orang mengalami stress. Hasil analisis uji Chi
Square diperoleh nilai $\mathrm{p}$ sebesar 0,003 yang berarti bahwa Wus penderita DM yang mempunyai pengetahuan tinggi berpengaruh secara signifikan untuk tidak mengalami stress akibat DM yang dialaminya. Nilai OR yang diperoleh sebesar 0,2 yang berarti bahwa Wus dengan pengetahuan tinggi mempunyai peluang untuk tidak stress sebesar 20\% dibandingkan Wus penderita DM yang pengetahuannya rendah. Hasil ini dapat disimpulkan bahwa pengetahuan yang tinggi berpengaruh terhadap Wus penderita DM untuk tidak mengalami gangguan psikologi.

Dari hasil analisis pada Tabel 3 di atas dapat disimpulkan bahwa variabel kesehatan fisik dan keterampilan dalam memecahkan masalah pada Wus penderita DM secara praktis dan statistik mempunyai pengaruh yang lebih besar untuk Wus tidak mengalami gangguan psikologi dilihat dari nilai OR sebesar 4,2 dibandingkan variabel tingkat pendidikan dan pengetahuan Wus penderita DM.

3. Analisis multivariabel

Selanjutnya dilakukan analisis multivariabel dengan menggunakan analisis regresi logistik. Pada analisis regresi logistik semua variabel bebas diuji secara bersama-sama terhadap variabel terikat. Variabel bebas yang diikutkan dalam regresi logistik adalah variabel bebas yang di dalam uji bivaribel sebelumnya mempunyai nilai $\mathrm{p}<=0,25$. Dari hasil uji bivariabel yang telah dilakukan, semua variabel bebas yaitu tingkat pendidikan, kesehatan fisik, keterampilan dalam memecahkan permasalahan dan tingkat pengetahuan Wus penderita DM mempunyai nilai di bawah 0,05 sehingga semua diikutkan dalam analisis regresi logistik. Hasil analisis multivariabel dengan regresi logistik secara keseluruhan disajikan pada Tabel 4.

Hasil analisis regresi logistik pada Tabel 4 terlihat bahwa secara umum variabel bebas pada penelitian ini 
berpengaruh terhadap psikologi Wus penderita DM dengan nilai $p$ di bawah 0,05 dan hanya variabel kesehatan fisik Wus penderita DM yang tidak bermakna secara statistik dengan nilai $\mathrm{p}>0,05$, tetapi masih bermakna secara praktis dilihat dari nilai OR yaitu 2,8.

Pada analisis regresi logistik Tabel 4 ada 2 variabel bebas yang mempunyai nilai praktis besar yaitu kesehatan fisik Wus, dan keterampilan memecahkan masalah Wus penderita DM dengan masing-masing OR 2,8 dan 12,0. Hasil ini dapat diartikan bahwa Wus penderita DM yang kesehatan fisiknya tidak terganggu mempunyai peluang untuk tidak stres sebesar 2,8 kali setelah dikontrol dengan variabel tingkat pendidikan Wus, keterampilan memecahkan masalah Wus, dan tingkat pengetahuan Wus penderita DM. Wus penderita DM yang mempunyai

Tabel 4. Pengaruh Tingkat pendidikan, kesehatan fisik, keterampilan memecahkan masalah dan tingkat pengetahuan terhadap psikologi WUS Penderita DM

\begin{tabular}{lcc}
\hline \multicolumn{1}{c}{ Variabel } & OR & P \\
\hline $\begin{array}{l}\text { Tingkat pendidikan Wus penderita DM } \\
\quad \text { Tinggi }\end{array}$ & 0,1 & 0,01 \\
$\quad$ Rendah & Ref & \\
$\begin{array}{l}\text { Kesehatan fisik Wus penderita DM } \\
\quad \text { Tidak terganggu }\end{array}$ & 2,8 & 0,40 \\
$\quad$ Terganggu & Ref & \\
Keterampilan memecahkan masalah & & \\
$\quad$ Terampil & 12,0 & 0,005 \\
$\quad$ Tidak terampil & Ref & \\
Tingkat pengetahuan Wus penderita DM & & \\
$\quad$ Tinggi & 0,1 & \\
$\quad$ Rendah & Ref & \\
\hline $\mathrm{N}$ & & 0,004 \\
$\mathrm{R}^{2}$ & & 0,35 \\
\hline
\end{tabular}

keterampilan menyelesaikan masalah terkait dengan permasalahan DM mempunyai peluang 12 kali untuk tidak mengalami stres setelah dikontrol dengan variabel tingkat pendidikan Wus, kesehatan fisik Wus, dan tingkat pengetahuan Wus penderita DM. Nilai $\mathrm{R}^{2}$ yang diperoleh pada analisis regresi logistik pada Tabel 5.4 sebesar 0,35 yang berarti bahwa variabel tingkat pendidikan Wus, kesehatan fisik Wus, keterampilan memecahkan masalah Wus, dan tingkat pengetahuan Wus penderita DM berkontribusi untuk Wus penderita DM tidak mengalami stres sebesar $35 \%$ sedangkan $65 \%$ dipengaruhi oleh faktor lain.

Diabetes melitus adalah salah satu penyakit tidak menular yang terjadi karena peningkatan kadar gula (glukosa) darah akibat kekurangan atau resistensi insulin di dalam tubuh. DM pada perempuan usia reproduksi perlu dicermati dan diwaspadai. Risiko yang terkait diabetes gestational adalah pra-natal morbiditas dan kematian serta peningkatan kelahiran sesar dan hipertensi yang kronis pada ibu. Wanita dengan diabetes gestational lebih cenderung melahirkan bayi besar yang merupakan alasan mengapa lebih banyak perempuan dengan diabetes gestasional melakukan sesar pada saat persalinan.

Wanita dengan diabetes sebelum kehamilan lebih cenderung memiliki bayi dengan cacat bawaan jika kontrol glikemik mereka dibawah optimal selama trimester pertama kehamilan. Dengan demikian 
sangat penting untuk semua wanita dengan diabetes untuk diberi konseling tentang risiko hiperglikemia dan kehamilan sebelum konsepsi dan untuk wanita dengan diabetes untuk merencanakan kehamilan mereka sehingga untuk mengurangi risiko cacat bawaan pada keturunan mereka (Weinger,at all, 2009). Oleh karena itu, pengendalian dan pencegahan hipertensi dan diabetes melitus pada WUS terutama sebelum hamil tentu akan berkontribusi terhadap penurunan angka kematian ibu dan bayi di Indonesia.

\section{Hubungan \\ Antara \\ Tingkat}

\section{Pendidikan WUS Penderita DM}

Terhadap Psikologi (Tingkat Stress)

Tingkat pendidikan WUS penderita

DM 70,6\% dalam kategori tinggi, dan dalam analisis bivariat menunjukkan bahwa tingkat pendidikan WUS penderita yang tinggi bermakna secara signifikan terhadap psikologi WUS. Pendidikan adalah bagian dari kebudayaan dan peradaban manusia yang akan terus berkembang. Kondisi pendidikan merupakan indikator dalam pengukuran tingkat pembangunan manusia suatu negara. Pendidikan akan memberikan kontribusi terhadap perubahan perilaku kesehatan melalui pengetahuan. Pengetahuan yang dipengaruhi oleh tingkat pendidikan merupakan faktor yang berperan untuk mempengaruhi keputusan seseorang dalam berperilaku sehat (Kemenkes RI, 2013).

Hasil ini juga diperkuat hasil penelitian Sativa (2015) yang menunjukkan hasil korelasi yang kuat antara dua variabel yaitu, variabel tingkat pendidikan dan variabel derajat depresi dengan $p<0,001$ yang menunjukkan korelasi bermakna. Dari angka koefisien korelasi yang didapatkan dapat diketahui bahwa korelasi antara kedua variabel bersifat negatif, yaitu semakin tingginya tingkat pendidikan maka semakin rendah derajat depresi pasien diabetes melitus.

WUS penderita DM dengan pendidikan tinggi cenderung untuk melakukan tindakan pencegahan, merubah perilaku untuk hidup sehat dan memanfaatkan layanan kesehatan dengan baik sehingga kecenderungan untuk terjadinya depresi sangat rendah. Pendidikan mempengaruhi daya serap seseorang terhadap informasi yang diterima. Seseorang dengan pendidikan yang baik lebih matang terhadap proses perubahan yang ada pada diri individu tersebut, sehingga lebih mudah menerima pengaruh luar yang positif, obyektif dan terbuka terhadap berbagai informasi termasuk informasi kesehatan.

2. Hubungan Antara Kesehatan Fisik Wus Penderita DM Terhadap Psikologi (Tingkat Stress)

Keadaan kesehatan fisik WUS penderita DM pada Tabel 5.1 terlihat bahwa $87,7 \%$ dalam keadaan tidak terganggu artinya bahwa walau pun WUS menderita DM namun tidak mengalami komplikasi. Dari hasil analisis bivariabel dapat dilihat bahwa kesehatan fisik Wus penderita DM dapat mencegah untuk tidak terjadinya depresi sebesar 4,2 kali dibandingkan yang kondisi kesehatannya terganggu.

Kesehatan fisik WUS penderita DM dipengaruhi oleh kualitas hidupnya. Pada penderita diabetes mellitus dengan adanya penurunan fungsi fisik yang secara tidak langsung akan berpengaruh pada keadaan psikologisnya seperti timbulnya perasaan cemas, depresi dan frustasi pada klien. Umumnya responden melakukan pengobatan secara rutin minimal sekali dalam sebulan hal ini akan sangat berpengaruh pada keadaan mood penderita, baik itu jangka pendek maupun jangka panjang. Komplikasi diabetes mellitus dapat menyebabkan depresi pada penderitanya.

3. Hubungan Antara Keterampilan Wus Penderita DM Dalam Memecahkan Masalah Terhadap Psikologi (Tingkat Stress)

Hasil analisis menunjukkan bahwa 64,7\% WUS penderita DM terampil dalam 
memecah masalah berkaitan dengan DM. Diperkuat pada analisis bivariat yang menunjukkan bahwa WUS yang terampil dalam memecahkan masalah terkait DM berpeluang 4,2 kali untuk tidak mengalami stress. WUS penderita DM yang memiliki keterampilan dalam memecahkan masalah maka pengambilan keputusannya juga positif hal ini sesuai dengan penelitian sebelumnya dimana kontrol diri mempengaruhi tingkat usaha dalam pengambilan keputusan dalam melakukan suatu perilaku (Evans, 2011).

Keterampilan WUS dalam memecah masalah berkaitan dengan DM terdiri dari empat tahap yaitu: 1) Intelligence, tahap ini merupakan proses penelusuran dan pendeteksian dari lingkup problematika serta proses pengenalan masalah; 2) Design, tahap ini adalah proses menemukan, mengembangkan, dan menganalisis alternatif tindakan yang bisa dilakukan. Tahap ini meliputi proses untuk mengerti masalah, menurunkan solusi, dan menguji kelayakan solusi, 3) Choice, tahap ini dilakukan proses pemilihan diantara berbagai alternatif tindakan yang mungkin akan dijalankan. Tahap ini meliputi pencarian, evaluasi, dan rekomendasi solusiyang sesuai untuk model yang telah dibuat; 4) Implementation, tahap iniadalah tahap pelaksanaan dari keputusan yang telah diambil. Pada tahap ini diperlukan untuk menyusun serangkaian tindakan yang terencana, sehingga hasil keputusan dapat dipantau dan disesuaikan apabila diperlukan perbaikan (Kadarsah, 2002).

Hasil penelitian sudah menunjukkan bahwa Wus yang mempunyai keterampilan memecahkan masalah berpeluang untuk tidak mengalami gangguan psikologi karena bisa menentukan tindakan yang tepat agar DM yang diderita tidak menjadi lebih parah.

\section{Hubungan \\ Antara \\ Tingkat \\ Pengetahuan WUS Penderita DM Terhadap Psikologi (Tingkat Stress)}

Pada penelitian ini 50\% lebih WUS penderita DM mempunyai pengetahuan yang tinggi. Dengan tingginya Wus penderita DM mengenal gejala hipoglikemia maka diharapkan wus penderita DM tidak mengalami komplikasi yang mengakibatkan gangguan secara psikologis. Dari hasil analisis bivariabel menunjukkan bahwa pengetahuan yang tinggi berpengaruh terhadap WUS penderita DM untuk tidak mengalami stres. Hal ini sejalan dengan pernyatan Smeltzer (2008) bahwa pengetahuan kesehatan yang berkaitan dengan pemberian informasi tentang monitor glukosa darah, komplikasi akut maupun kronik, pengelolaan peningkatan dan penurunan glukosa darah harus diberikan sedini mungkin atau sejak WUS pertama terdiagnosa DM.

Hasil ini juga diperkuat oleh Khan (2000) yang menyatakan bahwa pengetahuan tentang gejala hipoglikemia yang diperoleh oleh WUS akan dapat menentukan tindakan antisipasi dan intervensi terhadap gejala hipoglikemia. Dengan demikan akan menjadikan WUS tidak mudah mengalami stres.Pengetahuan merupakan domain penting terbentuknya tindakan seseorang. Pengetahuan diperoleh setelah seseorang melakukan peginderaan terhadap objek tertentu (Notoatmodjo S, 2010). Proses pembelajaran dimaksudkan untuk memberikan pengetahuanpada penderita sehingga terjadi perubahan proses informasi, pengambilan keputusan dan emosi yang pada akhirnya terjadi proses kontrol cognator dalam otak agar melakukan mekanisme belajar dan adaptasi. Dengan proses ini maka WUS penderita DM secara psikologi tidak terganggu sehingga dengan pengetahuan yang dimiliki membantu untuk tenang dan tidak mudah depresi.

Pengetahuan tentang hipoglikemia yang dimiliki WUS penderita DM akan memberikan dasar terhadap pemahaman tentang pengenalan, interpretasi gejala hipoglikemia dan pengambilan keputusan 
berupa intervensi baik secara mandiri maupun dengan bantuan orang lain. WUS Penderita DM dengan pengetahuan hipoglikemia yang baik akan memiliki kemampuan identifikasi terhadap respon tubuh akibat penurunan glukosa darah dan kemudian menginterpretasikan sebagai keaadaan yang memerlukan tindakan yang tepat. Tindakan yang tepat akan mencegah terjadinya depresi pada WUS penderita DM.

\section{SIMPULAN}

Berdasarkan hasil penelitian yang sudah dilaksanakan maka dapat diambil kesimpulan sebagai berikut:

WUS dengan pendidikan tinggi mempunyai peluang untuk tidak stress dengan nilai OR 0,2; WUS dengan kesehatan fisik tidak terganggu mempunyai peluang tidak stress dengan nilai OR 4,2; WUS dengan keterampilan memeacahkan masalah yang terampil mempunyai peluang tidk stress dengan nilai OR 4,2; WUS dengan pengetahuan tinggi mempunyai peluang untuk tidak stress dengan nilai OR 0,2 ; Tingkat pendidikan $(p=0,02)$, kesehatan fisik $(p=0,04)$, keterampilan memecahkan masalah $(p=0,006)$ dan tingkat pengetahuan $(p=0,003)$ WUS penderita DM berpengaruh secara sifnifikan terhadap psikologi (tingkta stress) WUS penderita DM dengan nilai $p<$ 0,05 . Pemakaian skala skoring yang bisa dimanfaatkan oleh tenaga kesehatan di pelayanan dan sebagai acuan pasien Diabetes Melitus sangat diperlukan.

\section{DAFTAR PUSTAKA}

Balitbangkes. Riset Kesehatan dasar Dalam Angka Provinsi Jambi. Jakarta. Balitbangkes. 2013

Bustan. Epidemiologi Penyakit Tidak Menular. PT. Rineka Cipta; Jakarta.2007.

Chew BH. Medication adherence on quality of life among adults with type 2 diabetes mellitus: An exploratory analysis on the EDDMQoL study.
Quality of Life Research; 2015; 24, 2723-2731.

Creswell J. Research Design: Qualitative and Quantitative. Approaches, London: SAGE Publications.1994

Departemen Kesehatan R.I. Laporan Hasil Riset Kesehatan Dasar Riskedas Indonesia Tahun 2007. Jakarta: Badan Penelitian dan Pengembangan Kesehatan.2008

Departemen Kesehatan RI. Pharmaceutical Care untuk Penyakit Diabetes Melitus. Jakarta: Depkes.2005.

Dinas Kesehatan Kota Jambi. Profil kesehatan Kota Jambi. Jambi: Dinkes Kota Jambi.2018

Guyton AC \& Hall JE. Buku Ajar Fisiologi kedokteran. Ed 9. Jakarta: EGC;2007.

IDF Diabetes Atlas Eighth Edition International Diabetes Federation. 2017.

IDF. Women and Diabetes. International Diabetes Federation; 2012

Kadarsah S. sistem Pendukung Keputusan: suatu wacana structural idealism. Bandung: PT Rodyakarya; 2002

Kemenkes RI. Profil Kesehatan Indonesia 2012.Jakarta. Kementrian Kesehatan Republik Indonesia.; 2013

Kemenkes. Laporan Riskesdas 2018. Jakarta.2018.

Khan AG, Azim A, Nadeem MA, Ayaz M. The effect of formaldehyde treatment of solvent and mechanical extracted cottonseed meal on the performance, digestibility and nitrogen balance in lambs.

Asian-aust. J.Anim.Sci.2000;13 (6): 785-790.

Lely dan Indrawati. Pengaruh kadar glukosa darah yang terkontrol terhadap penurunan derajat kegoyahan gigi penderita diabetes mellitus di RS Persahabatan Jakarta. Jakarta: Depkes.2004.

Notoatmodjo S. Promosi Kesehatan Teori dan Aplikasinya, Jakarta:Rineka Cipta; 2010. 
Nursalam. Konsep Penerapan Metode Penelitian Ilmu Keperawatan. Jakarta: Salemba Medika.2013

Perkeni. Konsensus Pengelolaan dan Pencegahan Diabetes Melitus Tipe 2 di Indonesia 2011. Jakarta Perkeni; 2011.

Potter PA. and Perry AG. Fundamental nursing: concepts, process, and practice. 6 th edition. St. Louis: Mosby Year book. 2005.

Price SA., Buku Patofisiology: Konsep Klinis Prose- Proses Penyakit (ed. 6) (Vol 2). EGC. Jakarta.

Restyana Noor Fatimah NR. Diabetes Melitus Tipe 2. J Majority; 2015; 4(5):93

Safarino, E.P. Health Psychology: Biospsychosocial Interactions, 5th Ed. USA: Jphn Wiley \& Sons. 2006.

Saraswati R. Hubungan antara Konsep Diri dengan Tingkat Depresi pada Penderita Diabetes Mellitus (DM) di Rumah Sakit Umum Ungaran. Tesis. Semarang, Undip.2010.

Smeltzer, S.c. \& Bare, B.G. Buku Ajar Keperawatan Medikal Bedah Volume 2. Ed 11. Jakarta: EGC; 2008

Sofiana. Hubungan antara Stress dengan Konsep Diri Pada Penderita Diabetes Mellitus Tipe 2. Jurnal Ners Indonesia; 2012; 2(2)

Wade C \& Tavris C..Psikologi. Ed 9. Terjemahan oleh Padang Mursalin dan Dinastuti. Jakarta: Erlangga; 2007.
Wahyuni S dan Alkaf. Diabetes Mellitus pada Perempuan Usia Reproduksi di Indonesia tahun 2007. Jurnal Kesehatan Reproduksi; 2013;3(1): 46 -51 .

Weinger, Katie;Catherine A. Educating Your Patient With Diabetes. Spinger Journal, 2019.

WHO. Glosbal Report On Diabetes. 2016 